Meta

Journal des traducteurs

Translators' Journal

\title{
Bologna, EMT and CIUTI - Approaches to High Quality in Translation and Interpretation Training
}

\section{Peter A. Schmitt}

Volume 57, numéro 1, mars 2012

La CIUTI, chef de file pour la promotion de l'employabilité et de la recherche

CIUTI: Leader in Advocating Employability and Research

URI : https://id.erudit.org/iderudit/1012738ar

DOI : https://doi.org/10.7202/1012738ar

Aller au sommaire du numéro

Éditeur(s)

Les Presses de l’Université de Montréal

ISSN

0026-0452 (imprimé)

1492-1421 (numérique)

Découvrir la revue

Citer cet article

Schmitt, P. A. (2012). Bologna, EMT and CIUTI - Approaches to High Quality in Translation and Interpretation Training. Meta, 57(1), 23-34.

https://doi.org/10.7202/1012738ar
Résumé de l'article

L'industrie, l'éducation, la formation et la recherche prêtent de plus en plus attention à la qualité des produits et services. Les différentes stratégies relatives à la traduction et l'interprétation en matière d'amélioration du contrôle de la qualité comprennent les normes génériques ISO9000 (apparues en 1987), ainsi que celles qui sont spécifiques à la traduction telles que les normes DIN 2345 (Allemagne, 1996), SAE J2450 (États-Unis, 2001, 2005) et DIN EN 15038 (Europe, 2006). Née en 1960, la CIUTI est un organisme pionnier dans le domaine de l'assurance qualité de la formation et de la recherche en traduction et en interprétation. La réforme européenne de la formation universitaire, le Processus de Bologne, qui s'est terminée en 2010, a été aussi l'occasion, pour les universités offrant la formation en traduction et en interprétation, d'améliorer leurs programmes. Enfin, le projet EMT, strictement centré sur les résultats en matière de compétences acquises, et récemment mis en place par la Commission de l'Union Européenne, constitue un autre moyen d'améliorer ces derniers. Le présent article décrit comment le Processus de Bologne, l'EMT et la CIUTI contribuent tous à la qualité en traduction.
Ce document est protégé par la loi sur le droit d'auteur. L'utilisation des services d’Érudit (y compris la reproduction) est assujettie à sa politique d'utilisation que vous pouvez consulter en ligne.

https://apropos.erudit.org/fr/usagers/politique-dutilisation/ 


\title{
Bologna, EMT and CIUTI - Approaches to High Quality in Translation and Interpretation Training
}

\author{
PETER A. SCHMITT ${ }^{*}$ \\ Universität Leipzig, Leipzig, Germany \\ schmitt@uni-leipzig.de
}

\begin{abstract}
RÉSUMÉ
L'industrie, l'éducation, la formation et la recherche prêtent de plus en plus attention à la qualité des produits et services. Les différentes stratégies relatives à la traduction et l'interprétation en matière d'amélioration du contrôle de la qualité comprennent les normes génériques ISO9000 (apparues en 1987), ainsi que celles qui sont spécifiques à la traduction telles que les normes DIN 2345 (Allemagne, 1996), SAE 2450 (États-Unis, 2001, 2005) et DIN EN 15038 (Europe, 2006). Née en 1960, la CIUTI est un organisme pionnier dans le domaine de l'assurance qualité de la formation et de la recherche en traduction et en interprétation. La réforme européenne de la formation universitaire, le Processus de Bologne, qui s'est terminée en 2010, a été aussi l'occasion, pour les universités offrant la formation en traduction et en interprétation, d'améliorer leurs programmes. Enfin, le projet EMT, strictement centré sur les résultats en matière de compétences acquises, et récemment mis en place par la Commission de l'Union Européenne, constitue un autre moyen d'améliorer ces derniers. Le présent article décrit comment le Processus de Bologne, l'EMT et la CIUTI contribuent tous à la qualité en traduction.
\end{abstract}

\section{ABSTRACT}

The quality of products and services, as well as methods of quality control are receiving more and more attention in industry, education, training and research. Translation and interpretation-related approaches towards better quality control include the generic ISO 9000 series (first published in 1987) as well as translation-specific standards such as the German DIN 2345 (1996), the American SAE J2450 (2001, 2005), and the European DIN EN 15038 (2006). CIUTI, an organization initiated in 1960, is the earliest approach to ensure high quality standards in translation and interpretation training and research. The European Higher Education Reform (Bologna Process), completed in 2010, was also a chance to improve the quality of university translation and interpretation programmes. Another and strictly outcome-oriented approach to improve translation quality is the relatively recent EMT project of the EU Commission. This paper describes how the different approaches of the Bologna Process, EMT, and CIUTI contribute to translation quality.

\section{MOTS-CLÉS/KEYWORDS}

qualité en traduction, qualité de la formation, Processus de Bologne, EMT, CIUTI translation quality, training quality, Bologna Process, EMT, CIUTI

\section{Background}

Since the 1970s, there has been an exponentially growing awareness of the importance of systematic quality assurance. Initially the focus was on physical products, but soon the issue of quality management, especially quality assessment and quality control, was extended to services. Today the quality of products and services, and 
methods of quality evaluation, are receiving much attention in industry, education, training and research. A key issue is, of course, the definition of the concept "quality." Various definitions may be found, ${ }^{1}$ but the most common definition is the one given in ISO 9000, clause 3.1.1: "The degree to which a set of inherent characteristics fulfills requirements."

In this definition, "requirements" are to be understood as a need or expectation that is stated, implied or obligatory (see ISO 9000, clause 3.1.2). The key idea is that "quality" - in this article and elsewhere - is a relative concept and not an absolute characteristic or feature of a product or service. The ISO 9000 series (first published in 1987) is of generic nature, but stipulates basic quality concepts, terms and processes that are also applicable to translation and interpretation (T\&I)-related products and services. Translation-specific standards include the German DIN 2345 (published in 1996, withdrawn in 2006 and replaced by DIN EN 15038), the American SAE J2450 (first published in 2001, updated in 2005), and the European EN 15038 (2006, currently under review) (for a comprehensive overview on translation-related standards, see Budin 2007). While standards provide a more conceptual framework for quality assurance, there are other efforts which aim at a high level of T\&I quality. Such efforts include the curriculum redesign required by the Bologna Process as well as the recent EMT initiative of the EU Commission's Directorate General for Translation (DGT). The longest-running T\&I quality assurance activity is CIUTI, an international association of T\&I institutes whose mission is to serve as a beacon of excellence in T\&I training and research.

The objective of all this is, essentially, to ensure the best possible interlingual and intercultural communication. The motivation behind it may be altruistic (to achieve a better understanding of peoples, which may eventually lead to world peace) or materialistic and economy-oriented (to facilitate globalization and world trade). However, these two - apparently opposed - motivations are interdependent. Even from a purely opportunistic point of view, an individual translator or interpreter has a vested interest in high standards of T\&I quality.

\section{Income, prestige, competence, quality of training - everything is interconnected}

The prestige and income of a profession is correlated to the competence of its members and to the quality of their products and services. Quality of training plays a central role here (see Lee-Jahnke 2009). It is influenced by various factors, such as the content of studies, but also the infrastructure of material and personnel, which in turn depends on the availability of competent teachers. For this reason, educational institutions for translators and interpreters have the task of producing graduates who are qualified for their profession and of recruiting suitable new teachers. Aspects that have provoked considerable controversy are the spectrum of competences needed in a very heterogeneous market, the role of translation theory or translatology in this context, but also the influence of the European Higher Education Reform ("Bologna Process") and the new bachelor's and master's degree programmes it created. There are different approaches to how a high training quality can be promoted on an international level (respecting at the same time heterogeneous national frameworks). The three most important (from a Eurocentric perspective) and newest approaches are 
European Higher Education Reform, the EMT network of the European Commission's Directorate-General for Translation, and CIUTI.

\section{European Higher Education Reform}

European Higher Education Reform, better known under the watchword "Bologna Process," has received plenty of media coverage, especially in 2010. The reason for this is that the regulations stipulated that the reform be put into practice by 2010 , and so first experiences with the new bachelor and master system have already been made. While some voices stress the positive effects of this reform (e.g., Schmitt 2006; 2007; 2011; Gaethgens 2009; Winter 2009) or express a balanced view (e.g., Schreiber 2010), these experiences seem to be largely negative according to the tenor of the media coverage. Kühl $(2009)^{2}$ derides the reform a "Planungsmonster" (planning monster), Reiser (2010) disseminates the apocalyptic perspective that "Bologna" will bring death to universities. But also at the higher education institutions themselves, teachers and students often give nothing but destructive comments: the central watch- and swearword is Verschulung, "school regimentation," but there are also complaints about the extreme pressure put on students, the excessive preparation needed for exams, inflexible modules and curricula, the lack of possibilities for study abroad, reduced mobility and the lack of a guarantee of a place in master's degree programmes. This certainly holds true for Germany, but it seems to apply to other European countries as well (see, e.g., Holzer 2011 and Sáenz 2011).

Given this recent criticism, which is often expressed as harshly as it is unjustified, it is appropriate to call to mind the objectives of the Higher Education Reform which the European education ministers stated in their joint declaration of 19 June 1999 in Bologna. ${ }^{3}$ One central point is mobility; two of the objectives directly consist in improving the quality of training and of graduates:

- Adoption of a system of easily readable and comparable degrees, also through the implementation of the Diploma Supplement, in order to promote European citizens employability and the international competitiveness of the European higher education system;

- Adoption of a system essentially based on two main cycles, undergraduate and graduate. Access to the second cycle shall require successful completion of first cycle studies, lasting a minimum of three years. The degree awarded after the first cycle shall also be relevant to the European labour market as an appropriate level of qualification. The second cycle should lead to the master and/or doctorate degree as in many European countries;

- Establishment of a system of credits - such as in the ECTS system - as a proper means of promoting the most widespread student mobility. Credits could also be acquired in non-higher education contexts, including lifelong learning, provided they are recognised by receiving Universities concerned;

- Promotion of mobility by overcoming obstacles to the effective exercise of free movement with particular attention to:

- for students, access to study and training opportunities and to related services; - for teachers, researchers and administrative staff, recognition and valorisation of periods spent in a European context researching, teaching and training, without prejudicing their statutory rights;

- Promotion of European co-operation in quality assurance with a view to developing comparable criteria and methodologies; 
- Promotion of the necessary European dimensions in higher education, particularly with regards to curricular development, interinstitutional co-operation, mobility schemes and integrated programmes of study, training and research.

(The Bologna Declaration, 19 June 1999; italicized by the author)

If today we have bachelor's and master's degree programmes that do not meet these objectives or that are inferior to the previous degree programmes in this respect, it is not because of "Bologna" (provided that the infrastructure or personnel structure have not deteriorated - which is unfortunately often the case), but because of the design of the degree programme. During the six years of my two terms of office as Dean of Students and Chair of the Programme Committee at the University of Leipzig, which coincided with the planning and adoption of the new degree programmes, and on account of my function as expert in accreditation procedures related to other universities, I often saw that some institutes undermine the reform objectives by introducing module concepts that eventually prevent mobility in the new graduate programmes.

The basic principle of modularity is the modules' function as "building blocks," i.e., their Lego-style exchangeability. In the first place, this does not mean their contents or order are arbitrary, but simply that it should be possible to select certain related sections of the course programme "en bloc" or to replace them with other (matching) "blocs" or modules. Students can do so by visiting suitable courses in other graduate programmes, at other institutes, other faculties, or even at another university in another country. Of course, if modules that extend over more than one semester are implemented (there are cases in which four-semester modules or modules which stretch over several non-successive semesters have been planned ${ }^{4}$ ), exchangeability is impossible, and it is not very surprising that such programmes prevent mobility.

The intention of the Reform was certainly not to just put a new label on existing graduate programmes and their old structures (see HRK $2010^{5}$ and KMK 20106). However, some institutes could not "resist the temptation" to "adapt [their old graduate programmes] to Bologna by subtly renaming them" (Forstner 2007: 124). On the contrary, Higher Education Reform offered a rare chance - that may not come back for years or even decades - to clear up and to renovate the existing graduate programmes thoroughly and really radically (see Schmitt 2007). It also offered a chance to introduce en passant, so to speak, a quality assurance system to the graduate programmes that really is worthy of the name. Today, teachers at higher education institutions are required to define learning objectives for each module and the courses it includes in advance and to specify not only the learning content to achieve these objectives, but also how to verify at the end of the module if they really have been achieved. For some teachers, this means that they have to rethink their concepts, and many of them have to invest more effort in course preparation and examinations. However, it is not the death of freedom in academic teaching (as implied by Reiser 2010) to have a clear didactic concept ${ }^{7}$ which is also transparent for students.

If it is understood correctly and put into practice in the right way, European Higher Education Reform is both an opportunity and the basis for finally fulfilling the requirements for the training of translators and interpreters that were specified back in 1986 in the BDÜ Memorandum, a sort of White Paper written by the presti- 
gious Koordinierungsausschuss Praxis und Lehre (coordination board for T\&I practice and training), a precursor of today's Transforum. ${ }^{8}$

During board meetings, for example, Hans J. Vermeer already used to point out that T\&I training is not "foreign language acquisition" and demanded that students must already have a high competence in their chosen working languages at the beginning of their studies. Higher education institutes of translation and interpreting are not "language schools," he said. At the time, this view was considered utopian and his ideas were rejected as unrealistic. Until recently, students were able to learn "nonschool languages" at T\&I institutes without any prior knowledge. However, language courses at the level of "me Tarzan, you Jane" have as little to do with university education as the typewriting courses of the 1950s to 1970s. This "language school" image still prevails for some institutes and hardly contributes to the positive reputation of professional interpreters and translators.

In the course of Higher Education Reform and maybe even as a result of the Bologna process, many institutes put an end to this. At IALT (Institut für Angewandte Linguistik und Translatologie) in Leipzig, for example, since the adoption of the bachelor's and master's degree programmes, applicants for the bachelor programme have had to demonstrate a language competence level ${ }^{9}$ of B1 (for English even B2) as an admission requirement. Additionally, there is an obligatory qualifying examination (experience shows that $60 \%$ of applicants with German as their mother tongue normally fail the German test included in it). ${ }^{10}$ By cutting elementary language courses, institutes have greater freedom to incorporate more up-to-date learning objectives and to teach currently needed competences.

At the time when the memorandum was written, the German words Translatologie and Translationswissenschaft (as compact generic terms for Übersetzungs- und Dolmetschwissenschaft, T\&I studies or the science of T\&I) were rather extravagant, even in the academic world, and were rarely used by scholars. ${ }^{11}$ The European Higher Education Reform and the obligation it brought with it to accredit the new graduate programmes have stimulated the words' propagation. Most institutes of translation and interpretation now have a " $\mathrm{T}$ " for translation in their name.

\section{The EMT network}

Another approach to promoting a high level of qualification for translators is the European Master's in Translation (EMT) project of the European Commission's Directorate-General for Translation (DGT). As detailed information is available on the DGT's website, ${ }^{12}$ I would like to mention just a few central points here.

As "EMT" stands for European Master in Translation, this means that the project is intended for translators, not for interpreters (since 1997, there is another project with a different concept initiated by the Directorate-General for Interpretation, the European Master in Conference Interpreting, EMCI, which I will not discuss in detail here $\left.{ }^{13}\right)$. Besides, the EMT is not, as is sometimes believed, an independent master's degree programme or master degree awarded by the EU (of course the European Commission does not have the right to confer academic degrees). "EMT" is a quality seal represented by a registered logo used to distinguish degree programmes which meet certain quality criteria. Higher education institutions offering master's degree programmes with an EMT quality seal form the so-called EMT 
network. The network's objective is not to distance itself in an elitist way from other graduate programmes. On the contrary, the EMT network is an open system. Its members are intended to serve as exemplary models for best practice in the field of translator training on the master level. In the ideal world, all master's degree programmes in translation will eventually achieve this quality level.

The question of how to evaluate the quality of a degree programme was (and still is) not trivial, even if such evaluations have been common for decades in rankings of higher education institutions ${ }^{14}$ worldwide. Of course, institutions which have achieved high rankings see no reason for openly questioning the validity of such quality assessments. However, more and more critical voices are being heard when it comes to the methods of data collection and the validity of these assessments. According to an article in the journal Welt Online, ${ }^{15}$ even Harvard University (which has no reason to complain about Harvard's ranking position) is also no longer willing to provide data for these rankings.

A binary quality assessment system which allows only Yes or No decisions (on the admission to the EMT network) is inherently problematic.

Furthermore, there are such big differences between countries, even within the EU and even after the European Higher Education Reform was completed, that it is impossible to dictate a standardized degree programme which could claim to provide the desired quality of training at anywhere in Europe. Even the term "master's degree programme," to give one example, is fuzzy as there are different combinations of bachelor's and master's degree programmes in Europe, and master's degree programmes can span one to two years.

Against this heterogeneous background, the DGT established an eight member "expert group"16 ad personam tasked to develop appropriate quality criteria. The result of many meeting sessions and much "homework" is a catalogue of competences that graduates from such a master's degree programme should have (see EMT expert group $2009^{17}$ ). It is irrelevant which course they have adopted during their studies in order to achieve those competences. This covers the options of attending a master's degree programme after the successful completion of a bachelor's degree in translation (at the same or at a different institute), or (if included in the respective study guideline) doing so after graduating from a bachelor's degree programme of another kind, (non-translational or a non-philological), e.g., a bachelor of science in mechanical engineering. ${ }^{18}$

Especially the last case makes it clear that these provisions raise some conceptual considerations if you want to ensure that both translatological-theoretical and translational-practical competences have been acquired during the studies. This is hard to achieve with an inflexible degree programme design. Vice versa, it is more difficult to quantify and "measure" the content of studies if the concept of a degree programme is characterized by various options, as is the case at IALT. Much depends on the options that are chosen individually and on the previous knowledge of students who enter the degree programme.

It is beyond question that it is impossible to turn somebody who has no previous translatological base into a technical translator with all competences required nowadays within a one-year master's degree programme. Unless students take the direct route of completing a translatological bachelor's degree programme at first before continuing on to a translatological master's degree at the same institute (e.g., 
in conference interpreting or in technical translation), they will not be able to avoid sitting a qualifying examination before being admitted to the master's degree programme.

The EMT competences framework (EMT expert group 2009; see note 15) includes 48 competences grouped into the categories translation service provision competence, language competence, intercultural competence, information mining competence, thematic competence and technological competence. The following skills and abilities are expected in detail:

- Knowing how to follow market requirements and job profiles (knowing how to remain aware of developments in demand)

- Knowing how to organise approaches to clients/potential clients (marketing)

- Knowing how to negotiate with the client (to define deadlines, tariffs/invoicing, working conditions, access to information, contract, rights, responsibilities, translation specifications, tender specifications, etc.)

[...]

- Knowing how to plan and manage one's time, stress, work, budget and ongoing training (upgrading various competences)

- Knowing how to specify and calculate the services offered and their added value

- Knowing how to comply with instructions, deadlines, commitments, interpersonal competences, team organisation

- Knowing the standards applicable to the provision of a translation service

- Knowing how to comply with professional ethics

- Knowing how to work under pressure and with other experts, with a project head (capabilities for making contacts, for cooperation and collaboration), including in a multilingual situation

$[\ldots]$

- Knowing how to create and offer a translation appropriate to the client's request, i.e., to the aim/skopos and to the translation situation

$[\ldots]$

- Mastering the appropriate metalanguage (to talk about one's work, strategies and decisions)

- Knowing how to proofread and revise a translation (mastering techniques and strategies for proofreading and revision)

[...]

- Knowing how to draft, rephrase, restructure, condense and post-edit rapidly and well (in languages $\mathrm{A}$ and $\mathrm{B}$ )

[...]

- Knowing how to use effectively and rapidly and to integrate a range of software to assist in correction, translation, terminology, layout, documentary research (for example text processing, spell and grammar check, the internet, translation memory, terminology database, voice recognition software)

[...]

- Knowing how to adapt to and familiarise oneself with new tools, particularly for the translation of multimedia and audiovisual material

- Knowing how to prepare and produce a translation in different formats and for different technical media

- Knowing the possibilities and limits of MT 
Even if this is just a small selection, ${ }^{19}$ it shows that nowadays many different things are expected from a translator. The message of this competence list is also addressed to clients and initiators of translations: Look what you can expect from a well-trained translator (and such a qualified professional will ${ }^{20}$ not work at dumping prices).

The institute filing an application must specify if it teaches these competences and correctly name the courses in which they are taught (of course, some courses may appear several times, e.g., seminars on technical translation that teach very complex clusters of competences). Even if these are minimum requirements (!) according to the expert group, it is difficult to realise all of them under the respective given frameworks.

For this reason, it is also part of the application to demonstrate that the institute filing it has the appropriate infrastructure of material and personnel at its disposal. This means, for example, a sufficient number of up-to-date computer workstations equipped with widely used translation-relevant software, a library with a suitable range of translatological volumes and journals (e.g., Fachsprache, Lebende Sprachen, MDÜ, Meta, Target), rooms with the required didactic-technical equipment and a sufficient number of teaching personnel with the right qualifications. It is equally important to document the percentage of courses held by teachers with professional experience in translating.

Last but not least, the respective graduate programme must be state-approved, there must already be graduates from it and it must be documented (e.g., by questioning alumni) what percentage of graduates are successfully employed or self-employed. ${ }^{21}$ This means that documenting an EMT application presents a relatively high effort to all the people involved in it (which could in fact discourage application). Additionally, membership in the EMT network is time-limited (experience shows that graduate programmes change and that quality often stands or falls with certain teachers), so at certain intervals, membership has to be extended by applying again. In spite of these high hurdles, more than 150 institutes in the EU applied since the programme was started at the beginning of 2009. To apply, all these institutes submitted piles of documents which had to be checked by the Expert Group, supported by DGT employees. Only about one third of the applicants met the quality criteria. By July 2011, the EMT Network had 54 members. ${ }^{22}$

\section{CIUTI}

CIUTI (Conférence Internationale Permanente d'Instituts Universitaires de Traducteurs et Interprètes) in essence shares the same objective as EMT. The origins of the organisation can be traced back to an initiative by the Universities of Geneva, Heidelberg, Mainz/Germersheim and Paris-Sorbonne in 1960. In 1964 this group, together with three more partners (Saarland University, the Universities of Trieste and Vienna) founded an association with the name Conférence Internationale Permanente de Directeurs d'Instituts Universitaires pour la formation de Traducteurs et d'Interprètes, abbreviated to CIUTI. ${ }^{23}$ It is established under Belgian law with the following objectives according to Article 3 of its statutes:

Art. 3. La CIUTI, qui est dénuée de tout esprit de lucre, a pour mission:

- D’optimiser la qualité de la formation; de faciliter la mobilité des étudiants et des professeurs entre les instituts membres. 
- D’assurer la collaboration de ses membres dans le domaine de la recherche, dans le développement de nouvelles méthodes d'enseignement.

- De promouvoir les relations avec les organisations, les associations et les entreprises nationales et internationales, portant intérêt à la formation de professionnels de l'interprétation, de la traduction, de la communication multilingue et interculturelle.

(CIUTI Statutes, updated 9 May 2008)24

It becomes clear that the CIUTI anticipated and formulated central objectives of the European Higher Education Reform - especially the promotion of student and teacher mobility - as long as fifty years ago. Since then, CIUTI has also pursued the EMT network's objective of safeguarding translator and interpreter training based on state-of-the-art courses of study, didactics and practice.

But there are also fundamental differences. As the "I" in its name signalises, in contrast to the "E" in EMT, CIUTI is not limited to Europe, but operates on a truly international level. For this reason, institutes in Beirut, Minsk, Monterey (California), Montréal, Beijing, Saint Petersburg, Shanghai, Seoul and, to name another non-EU member, Geneva, are members of CIUTI as well. ${ }^{25}$

The fact that after fifty years CIUTI still has "only" 40 members, whereas the EMT network has acquired 54 members within two years after its implementation (even if it is more regionally restricted), shows another difference: the admission procedure to CIUTI is even more selective and even stricter than for the EMT network.

Originally there was another restriction expressed by the " $U$ " in CIUTI: At first, non-university higher education institutions were not eligible for CIUTI membership. Now, however, polytechnics and German Fachhochschulen ("universities of applied sciences") can also apply for membership.

On the other hand, CIUTI membership is not limited to institutes offering translator training. Much attention is also paid to high-quality training in conference interpreting.

A big difference between CIUTI and EMT is the importance of T\&I research. Applicants for CIUTI membership must demonstrate that they are not merely "translation trainers" (even if they are very successful in this regard) but also productive and respected in T\&I research, e.g., in terms of publications, conferences, doctorate programmes, number of Ph.D. graduates.

Maybe the key difference is the fact that with EMT only a specific master's degree programme can obtain the EMT quality seal, but not the entire institute. With CIUTI, the institute as a whole becomes a member, i.e., the CIUTI membership guarantees that the entire institute meets high quality standards, even if it may have a broad range of graduate programmes.

The CIUTI admission procedure lasts one year after the Secretariat-General receives the admission application. In addition to checking its documentation (similar to EMT), two neutral ${ }^{26}$ university teachers are sent to the applying institute at its expense. They inspect the facilities and didactical-technical equipment (e.g., simultaneous interpretation training systems, language laboratories, computer workstations, auditoriums and seminar rooms with data projectors etc.), check the holdings in the library and its availability, talk to teachers and students, sit in on courses, are present at interpretation examinations, check written examinations, bachelor's and master's theses. An admission commission assesses the evaluation results from the documentation and visits on site and writes a recommendation for admission or 
non-admission. This is presented to CIUTI members at the annual General Assembly as a basis for their decision.

Given these requirements and efforts, it is understandable why the circle of CIUTI members is growing only at a very slow rate and that CIUTI projects a certain elitist image (which is indeed even cultivated and relished by some members).

\section{Conclusion}

We are experiencing a growing awareness of the importance of good training - in all professions. In the T\&I field, we enjoy the combined, if not concerted, efforts of the European Higher Education Reform, the EMT and EMCI initiatives by the EU DGT and SCIC, respectively, and by the CIUTI. Supported by activities on a national level (such as ongoing training offered by professional associations and T\&I institutes, as well as regular meetings of committees such as the German Transforum), there is reason to hope that translators and interpreters might reclaim their social standing as well-educated (and correspondingly well-paid) academics.

\section{NOTES}

* IALT (Institut für Angewandte Linguistik und Translatologie).

1. The current Wikipedia article on "quality" lists twelve definitions. Visited on 15 July 2011, <http:// en.wikipedia.org/wiki/Quality_\%28business\%29>.

2. KüHL, Stefan (3 December 2009): Das Planungsmonster. Süddeutsche Zeitung. 279:11.

3. Occasionally, one may get the impression that not everybody who comments on the Bologna Process has actually read the Bologna Declaration. It can be easily found on the Internet, e.g., in Wikisource (Bologna Declaration of 19 June 1999. Visited on 25 July 2011, <http://en.wikisource. org/wiki/Bologna_Declaration_of_19_June_1999>). See also the clarifying comments on the Declaration: CONFEDERATION OF EU RECTORS' CONFERENCES AND THE ASSOCIATION OF EUROPEAN UNIVERSITIES (2000): The Bologna Declaration on the European space for higher education: an explanation. Visited on 25 July 2011, <http://ec.europa.eu/education/policies/educ/ bologna/bologna.pdf>.

4. It is the function of accreditation experts to prevent that such violations of the Bologna concept are actually implemented.

5. HRK [HOSCHSCHULREKTORENKONFERENZ] (2010): Bologna-Prozess im Überblick. Visited on 28 November 2010, <http://www.hrk.de/bologna/de/home/1916.php>.

6. KMK [KULTURMINISTERKONFERENZ] (2010): Bologna-Prozess. Visited on 28 November 2010, $<$ http://www.kmk.org/wissenschaft-hochschule/internationale-hochschulangelegenheiten/bologna-prozess.html>.

7. The concept should always be accessible for students, e.g., on the institute website; this is one of many evaluation criteria for admission to the EMT network.

8. TRANSFORUM. Visited on 25 July 2011, <http://www.transforum.de $>$. This body was initiated by the BDÜ (with about 6,000 members Germany's most influential professional association of translators and interpreters). Twice a year, about 40 representatives of all German T\&I institutes and all areas of the T\&I market meet for two days to exchange views and learn about new developments in their respective areas.

9. According to the Common European Framework of Reference for Languages; for an overview of the competence levels see e.g., Gemeinsamer Europäischer Referenzrahmen, visited on 25 July 2011, $<$ http://de.wikipedia.org/wiki/Gemeinsamer_Europ\%C3\%A4ischer_Referenzrahmen>.

10. It usually is sufficient to achieve $60 \%$ of total maximum points. See also Schmitt 2010.

11. At the same time, and for good reasons, Justa Holz-Mänttäri - who travelled all the way from Finland to participate in most of the Koordinierungsauschuss meetings and contributed to the Memorandum - propagated the rather cumbersome term Botschaftsträgerverbund (messagetransmitter compound) instead of text. However, this term has not gained acceptance. 
12. EUROPEAN COMMISSION, DIRECTORATE-GENERAL FOR TRANSLATION, European Master's in Translation. Visited on 25 July 2011, <http://ec.europa.eu/dgs/translation/external_relations/universities/emt_network_join_de.htm $>$.

13. EUROPEAN MASTER IN CONFERENCE INTERPRETING, visited on 25 July 2011, <http://www. emcinterpreting.org/>. More information will be found on this site.

14. In Germany, the best-known system is the CHE-Ranking initiated by the Bertelsmann Foundation and supported by the German Rectors' Conference (HRK); for more information see <http://www. che-ranking.de>, visited on 25 July 2011.

15. Vom Lehn, Birgitta (5 July 2009): Uni Kiel steigt aus dem Hochschulranking aus. Welt Online. Visited on 25 July 2011, <http://www.welt.de/wams_print/article4060480/Uni-Kiel-steigt-aus-demHochschulranking-aus.html>.

16. The members of this expert group came from different EU states and held different positions. This gave them a good overview of both the training and the job market for translators.

17. EMT EXPERT GROUP (2009): Competences for Professional Translators, Experts in Multilingual and Multimedia Communication. 7 p. Visited on 28 November 2010, <http://ec.europa.eu/dgs/ translation/programmes/emt/key_documents/emt_competences_translators_en.pdf $>$.

18. The fact that people often talk or write about "B.A. " or "M.A." when they mean bachelor or master shows that they often ignore this option explicitly intended by the reform because they only think of the bachelor or master of arts (B.A. or M.A.), but not of sciences (B.Sc. or M.Sc.).

19. Even "grown translators" will find it interesting to read the entire list.

20. Sadly, a more realistic word is: should.

21. As it is impossible to enlarge upon the problem in detail, I would only like to point out that it is often difficult to say, given the diversity of jobs a graduated translator or interpreter can do, if a certain occupation is directly linked to the skills and abilities learned during T\&I studies. There is a smooth transition from being a translator to occupations like terminologist, technical writer, software developer, training manager, travel agency manager, tour guide, tourist animator or table dancer.

22. EUROPEAN COMMISSION, DIRECTORATE-GENERAL FOR TRANSLATION. European Master's in Translation. Visited on 14 February 2012, <http://ec.europa.eu/dgs/translation/programmes/emt/>.

23. CIUTI. Visited on 25 July 2011, <http://www.ciuti.org $>$.

24. CIUTI Statutes (updated 9 May 2008). Visited on 25 July 2011, <http://www.ciuti.org/about-us/ statutes/>.

25. For a complete list, see CIUTI Members. Visited on 25 July 2011, <http://www.ciuti.org/members/>.

26. This means that visiting teachers should be as impartial as possible. Consequently, they must come from a different country and not from an institute that is competing in any way with the applying institute.

\section{REFERENCES}

Budin, Gerhard (2007): Entwicklung internationaler Normen im Bereich der Translationsqualität bei ISO/TC 37. In: Peter A. Schmitt und Heike Jüngst, eds. Translationsqualität. Frankfurt am Main: Peter Lang, 54-65.

Forstner, Martin (2007): Paralipomena zur Diskussion über die Qualität von Translationsstudiengängen unter dem Bologna-Regime. In: Peter A. Sснмiтt and Heike JüNGst, eds. Translationsqualität. Frankfurt am Main: Peter Lang, 124-157.

Gaehtgens, Peter (2009): Bologna tut not - Ein Plädoyer. Forschung \& Lehre. 6:418-419.

Holzer, Peter (2011): Die Universitätsreform in Österreich und ihre Auswirkungen auf die Ü/D-Institute. In: Peter A. Schmitt, Susann Herold and Annette Weilandt, eds. Translationsforschung - Tagungsberichte der LICTRA IX. Leipzig International Conference on Translation \& Interpretation Studies, 19 - 21 May 2010. Vol. 1. Frankfurt am Main: Peter Lang, 333-342.

Lee-Jahnke, Hannelore (2009): Doppelter Praxisbezug und Kompetenzenvermittlung als Problem der Qualitätssicherung translatorischer Studiengänge. In: Martin Forstner, Hannelore Lee-Jahnke and Peter A. Schmitt, eds. CIUTI Forum 2008: Enhancing Translation Quality: Ways, Means, Methods. Frankfurt am Main: Peter Lang, 133-194. 
ReISER, Marius (2010): Bologna: Anfang und Ende der Universität. Forum 80, Bonn: Deutscher Hochschulverband.

SÁenz, José Manuel (2011): Chancen der Bologna-Reform in Spanien: Übersetzungs- und Dolmetschausbildung im Doppelstudium mit Internationalen Beziehungen. In: Peter A. Schmitt, Susann Herold and Annette Weilandt, eds. Translationsforschung - Tagungsberichte der LICTRA IX. Leipzig International Conference on Translation \& Interpretation Studies, 19 - 21 May 2010. Vol. 2. Frankfurt am Main: Peter Lang, 691-700.

Schmitт, Peter A. (2006): Bologna in Saxony: Benefits and Problems of the New T\&I Curriculum at the IALT. Proceedings of the 6th International Conference on Translation and Interpretation Studies. Seoul: Hankuk University of Foreign Studies.

Sснмiтt, Peter A. (2007): Der Bologna-Prozess als Chance zur Qualitätssteigerung der neuen Bachelor- und Master-Studiengänge. In: Peter A. Sснміт and Heike JüNgst, eds. Translationsqualität. Frankfurt am Main: Peter Lang, 520-536.

Schmitт, Peter A. (2010): Exams in T\&I Theory - Reflections on the Leipzig approach. In: Nadja Grbić, Gernot Hebenstreit, Gisella Vorderobermeier, et al., eds. Translationskultur revisited - Festschrift für Erich Prunč. Tübingen: Stauffenburg, 261-278.

Sснмітт, Peter A. (2011): «Bologna» - ein kapitaler Fehler? In: Peter A. Sснмiтt, Susann Herold and Annette WeILAndt, eds. Translationsforschung - Tagungsberichte der LICTRA IX. Leipzig International Conference on Translation \& Interpretation Studies, $19-21$ Mai 2010. Vol. 2. Frankfurt am Main: Peter Lang, 711-731.

SChreiber, Michael (2010): Bologna hin und zurück: Brauchen wir eine Reform der Reform der Studiengänge? In: Hannelore Lee-Jahnke and Erich Prunc, eds. Am Schnittpunkt von Philologie und Translationswissenschaft. Festschrift zu Ehren von Martin Forstner. Bern: Peter Lang, 323-334.

Winter, Martin (2009): Bologna 2.0? Vermeintliche, vermeidbare und echte Probleme der Studienstrukturreform. Forschung \& Lehre. 6:410-412. 